\title{
Islamic Studies Library: \\ Growth and Evolution
}

\section{by Sean Swanick}

\begin{abstract}
The Islamic Studies Library (ISL) was founded in 1952 in conjunction with the Institute of Islamic Studies (IIS). The founder, Dr. Wilfred Cantwell Smith, persuaded Principal F. Cyril James in 1951 that the study of Islam at McGill University was a worthwhile pursuit. From 1952 to the present, the ISL has grown from a modest 250 books to a collection of over 150, 000 volumes. The Library works to highlight and illustrate the breadth of Islamic civilization. This paper examines the ISL's growth and evolution in its 60 years of existence.
\end{abstract}

\section{RESUMÉ}

La Bibliothèque d'études islamiques (BEI) fut fondée en 1952 en conjonction avec l'Institut d'études islamiques (IEI). Le fondateur, le docteur Wilfred Cantwell Smith, a persuadé le Principal F. Cyril James en 1951 qu'il serait souhaitable que les études islamiques deviennent un domaine d'activité à l'Université. Dotée en 1952 d'une modeste collection de 250 livres, la BEI possède aujourd'hui plus de 150000 volumes. La Bibliothèque vise à mettre en relief et à illustrer l'ampleur de la civilisation islamique. Cet article examine la croissance et l'évolution de la BEI au cours de ses 60 années d'existance.

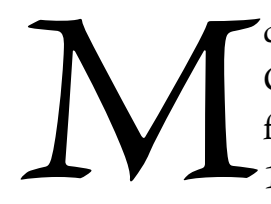
cGill University was founded by royal Charter from King George IV in 1821 following a bequest by James McGill (17441813), a Montreal merchant from Scotland who sought to nurture higher education in Lower Canada. In 1829 Medicine became McGill's first faculty and provided also the University's first library. In 1893 Redpath Library opened on McTavish Street as Canada's second free-standing academic library building, receiving major additions in 1901, 1921, and 1953. In 1969, McGill opened McLennan Library, contiguous with Redpath Library, as the University's new main library building. McGill's Library system now includes eleven libraries, designed to meet the teaching and research needs of faculty, students and staff. ${ }^{1}$

The Faculty of Divinity, established in 1948 but with roots extending back to the mid- $19^{\text {th }}$ century, hired a Professor of Comparative Religion, Dr. Wilfred Cantwell Smith (19162001) who in the early 1950's sought to give greater shape to this field through creation of an Islamic studies program. Principal F. Cyril James agreed to this proposal, and in May, 1951 named Smith the first Director of the Institute of Islamic Studies, Faculty of Graduate Studies. ${ }^{2}$

Dr. Smith envisioned for the Institute an "emphasis...on Islam as a contemporary and living force. ${ }^{3} \mathrm{He}$ strove to create a place of study in which Muslim and Christian students from East and West could sit side-by-side to foster interfaith dialogue and understanding. Smith also encouraged development of a specialized library for Islamic studies.

The Institute and Library both reflect Dr. Smith's background and vision as a scholar par excellence whose interests in the Muslim world stemmed from his having lived, studied and taught in India and Pakistan. ${ }^{4} \mathrm{He}$ recognized the need for dialogue between Western and Islamic civilizations that had much in common, but also harboured much misunderstanding of one another. The experience encouraged Smith to found an academic program that would promote interfaith dialogue.

The purpose of this paper is to discuss the early development of the Islamic Studies Library and some of the challenges it has faced, particularly from a collections development perspective. The Library maintains one of North America's most prominent collections in the field and shares the distinction, with Robarts Library, University of Toronto, of having Canada's largest and most diverse Islamic collection. Although collections have developed in other Canadian universities, such as Simon Fraser University's Centre for the Study of Muslim Civilization-modelled after McGill's Institute of Islamic Studies-no other University in the country boasts a more significant collection than McGill. Its unique holdings and rare books collections, in Middle Eastern and other languages, rank the Library among the finest Islamic Studies libraries in North America. 
As the oldest such collection in Canada, and the only one devoted exclusively to Islamic Studies, the Library reflects the growing maturity of Canadian librarianship, and the country's striving for cultural diversity and understanding. The adventure of the Islamic Studies Library may be situated in three stages: Early Years (1952-1984), Partington Report, 1984, and Recent Developments.

\section{Background}

The Islamic Studies Library like other McGill libraries focuses upon serving specific academic needs. Archival documentation for the early years hardly differentiates between the Library and the Institute. This close alignment has meant, on the one hand that the financial backing of the Library in its early years was left to the Institute's Director and faculty, and on the other hand that the Library's management resided during these years solely with its librarians and the Director of the Institute. Dr. Smith's success in obtaining start-up grants for the Institute and the Library from the Ford and Rockefeller Foundations, insulated and isolated the Library from the McGill Library system. ${ }^{5}$ Another factor contributing to the Library's relatively independent status until the early 2000s may have also been the specialized nature of its collections, particularly its language holdings. Unlike several other specialized McGill collections, the Islamic Studies Library has retained its separate housing and not been merged with another collection, or relocated to the McLennan Library.

Graduate students have always been the focus of the Institute, which in its early years had no undergraduates. For many years, the full complement of students, faculty and staff averaged about 25 people. ${ }^{6}$ This ability to remain small permitted a strong sense of community, with faculty, students, and staff, during Smith's era. In fact, for many of the early years faculty, students and staff would congregate for tea time together. This community spirit encouraged one student to state that

he had learned more of Islam from his experience of washing tea cups with a Muslim fellow-student than he had in his classroom experience. ${ }^{\text {? }}$

In addition to students and scholars, the Institute has attracted over the years a wide range of dignitaries. Former Tunisian President, Habib Bourguiba visited in 1959, and gave the Library a Qurannic leaf, now housed in McLennan's Rare Books and Special Collections. ${ }^{8}$ In 1965 the late Shah of Iran, Mohammad Reza Pahlavi, during his visit donated a collection of Persian monographs. In 2010, the Hon. Mackenzie Clugston, Canadian Ambassador to Indonesia and the Association of Southeast Asian Nations, and Hon. Ferry de Kerckhove, former Canadian Ambassador to Egypt, visited the Institute and Library.
In terms of collections, the Library began with very small holdings, supplemented, however, by other modest, yet important Islamic Manuscripts collections held at McGill in the Osler History of Medicine Library and McLennan Library's Rare Books and Special Collections. The Osler collection, created by Sir William Osler (18491919), contains 130 Arabic and Persian manuscripts and one Ottoman-Turkish manuscript. ${ }^{9}$ The Rare Books and Special Collections Division holds two Islamic manuscript collections: the Blacker-Wood collection containing 300 manuscripts in Arabic, Persian and Urdu selected by the Ismaili scholar, Dr. Wladimir Ivanow (1886-1970) between 1925 and $1930^{10}$; and the Islamic collection containing 200 manuscripts in Arabic, Persian, Ottoman Turkish and Urdu. The role of Dr. Casey Wood (1856-1942), a renowned ophthalmologist, bibliophile, and McGill benefactor in developing these collections also deserves acknowledgement. As for the Islamic Studies Library, it holds over 200 manuscripts in Arabic, Persian, Ottoman Turkish and Urdu. Overall, McGill's Islamic manuscript collections now total approximately 700 items.

Use of these manuscript collections for academic projects has been greatly assisted by Adam Gacek's catalogues integrating the holdings of all three collections. ${ }^{11}$ A global project is currently underway, led by A. Gacek, Pam Miller (Osler Library), Dr. F. Jamil Ragep (Director of the Institute), and Dr. Faith Wallis (Dept. of History), analyzing the collections' most prominent manuscript, the nearly complete medicinal Herbal by Aḥmad ibn Muhammad al-GhāfiqīKitāb al-'adwiya al-mufrada (Book of Simple Drugs). ${ }^{12}$ A recent graduate student, Bogdan Smarandache, has used the collection in a forthcoming article on al-Majūsis's Kämil al-Sināah and the Wafā'îyah Sufi Order in Ottoman Egypt. ${ }^{13}$ The collections have also been the focus of several exhibitions in the McLennan Library: in 1973 on Persian and Arabic manuscripts ${ }^{14}$; in 1990 "Scribes and Scholars" on calligraphy ${ }^{15}$; in 2011 "Abū-Ḥāmid al-Ghazālī (1058-1111): Celebrating 900 Years," on the scholar al-Ghazăli16; "Book Culture in the Medieval Mediterranean" which highlighted book practices from the Mediterranean basin; and most recently in 2013 "Strokes and Hairlines: Elegant Writing and its Place in Muslim Book Culture" highlighting the importance of book culture in the cultural and religious history of Islam.

The Institute and Library for many years led a peripatetic existence. When the Institute first opened it was part of the Faculty of Divinity, now called the Faculty of Religious Studies, located in the Birks building. In 1957 the Institute moved to Cottingham House a four-storey mansion on Redpath Crescent which permitted expansion of the Library. ${ }^{17}$ Seven years later in 1964 the Institute and Library moved to the 9th floor of the newly opened Leacock building. In 1983, they both moved yet again to their current home, Morrice Hall, which was gutted and rebuilt to meet their needs. 


\section{Early Years (1952-1984)}

At the institute's 1952 inauguration. Dr. Smith noted the importance of an Islamic Studies Library:

"my thesis is that the development of good Islamic Libraries, and of good Islamics Librarianship, is an intellectual task of the first order - one that requires technical skill in the librarian's craft, plus an authentic understanding of Islamic culture and civilization and even faith, plus an ability to synthesize these creatively." 18

These words set the tone for the Library even if it possessed barely 250 monographs, and was providing service during the first year for only six graduate courses, offered by three professors. Some of the early issues facing the Library were related to space, others related to cataloguing monographs-challenging yet surmountable tasks. When the Library first opened Dr. Smith was effectively Head librarian, although Dr. F.R.C. Bagley, lecturer in Arabic and Persian languages, served as part-time librarian. When William J. Watson became librarian in 1955, Bagley resumed full-time teaching. ${ }^{19}$
The Institute's initial goal was to provide "special emphasis to Islam as a religion, and to present-day developments in the Muslim world" ${ }^{20}$ through serving as a small graduate centre with a focus on research. This emphasis on teaching and researching Islam's past and present would ultimately require large-scale acquisition of publications from countries with predominantly Muslim populations. For reasons of space, and financial limitations, the Library emphasized Islam in the Arab Middle East, Turkey, Indonesia, Pakistan and India.

In September, 1954, to assist with the acquisition and organization of publications in Islamic languages such as Arabic, Baluchi, and Urdu, Dr. Smith wrote a "Memorandum on Library Development." This document illustrates his passion for libraries in general as well as his acute knowledge and understanding of the differing library traditions of Eastern and Western peoples. Smith noted that:

the body of knowledge, the conventions, the techniques and procedures that constitute [librarianship], and also the underlying concepts, some explicit and others unconscious, that undergird it, are a reflection, as they have been a product, of Western civilisation. ${ }^{21}$

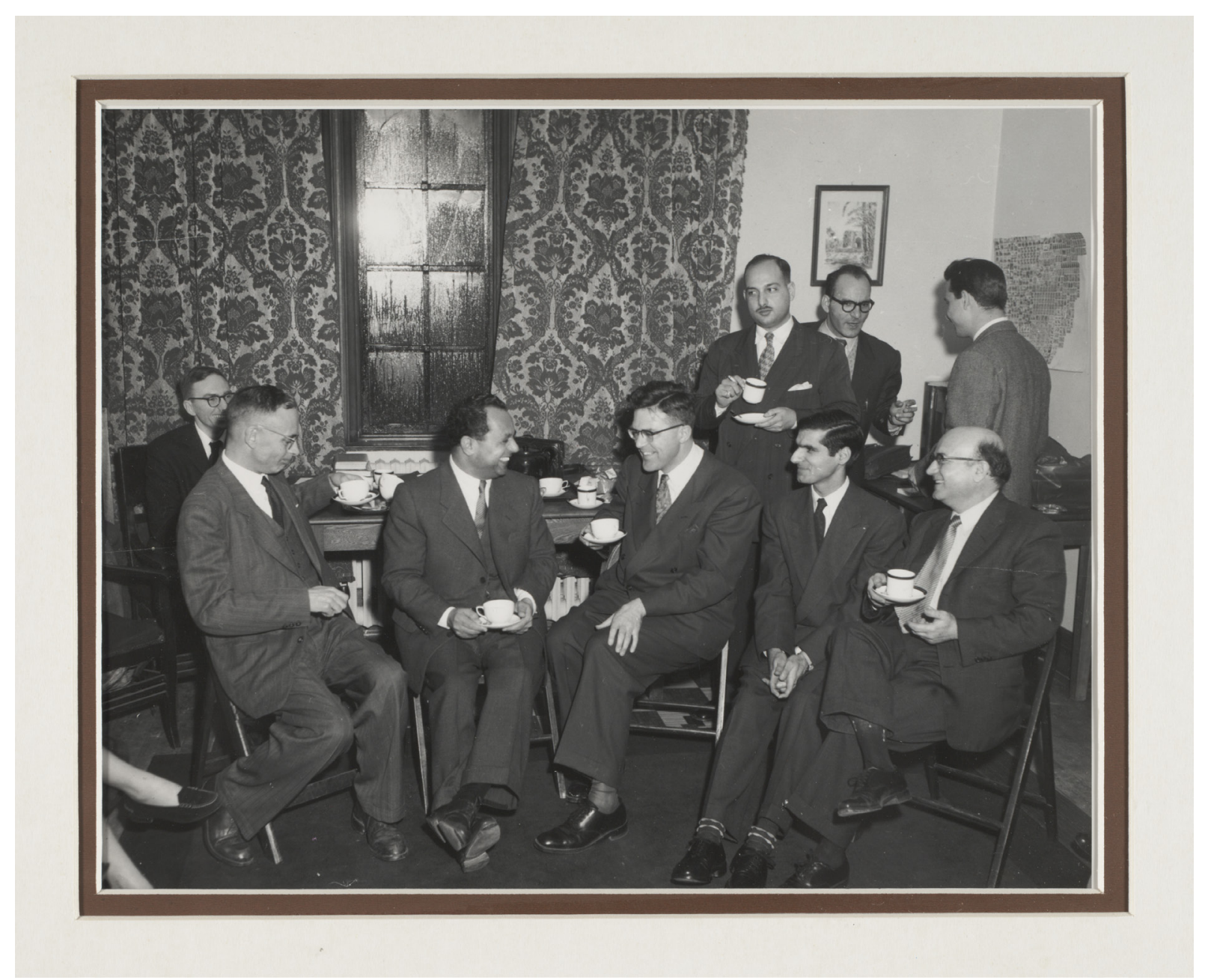

Figure 1. Tea time at the Institute of Islamic Studies, c. 1955 (Smith seated in the centre) 
The Memorandum explores the challenges faced in acquiring library materials from the Islamic world and notes three major issues in creating an Islamic Studies Library: i) the acquiring of books; ii) the processing of books; and iii) the training of personnel. All three are related in that the core requirements for a librarian in this field are linguistic ability and an understanding and sympathy for the Islamic world. These challenges and requirements persist to the present day.

The acquisition of books from the Islamic world remains a persistent issue, with many research libraries sending specialised librarians and other staff directly to Islamic countries to purchase materials. Although acquisition of materials from the Islamic world has improved dramatically, Paul Sprachman-former Middle East librarian at the University of Chicago - noted in 1982 that:

book buying in the Middle East involves tracking down someone who knows someone else who has valuable materials, drinking countless cups of tea and praising the tea, not the books. ${ }^{22}$

The problem of classifying Islamic materials was remedied for the Library in 1960 when Smith and William J. Watson, librarian of the Islamic Studies Library (1955-1965) devised the "Smith-Watson Classification system" to accommodate Islamic publications. As Smith noted, librarianship was a Western affair with developed systems, classification and otherwise, for Western materials and Western libraries. The Dewey decimal classification system, the Library of Congress classification and cataloguing systems, their name and subject authority files, and the UNESCO systems, are examples of universal bibliographical control mechanisms that did not easily accommodate Islamic publications. ${ }^{23}$

The Smith-Watson Classification system divided Islamic studies into five categories:

1) Reference materials;

2) Extra-Islamic subjects (including Religion/

General, Orientalism and Orientalists; History,

Economics, Politics, and Law, among other topics);

3) Islam, Classical Period, i.e. prior to 1800;

4) Modern Islamic World, i.e. post 1800; and

5) General Geographical Divisions.

These five categories, each with 5-12 subcategories, were used to classify the Library's collection.

Although the Smith-Watson Classification system was a major accomplishment, it remained a McGill novelty and would be adopted by no other Islamic or Middle East Library in North America or beyond, due partly to lack of resources for further development. In the 1980s, the Library of Congress classification system began adapting to better meet the needs of Islamic publications. Previously, LC classification's had suffered from a Western-centric perspective, with Islam subsumed under Christianity. Development of the BP class permits a broader and less-Western centric classification of materials on or about Islam. A continuing drawback is that the BP class is not reserved exclusively for Islam, but is also used to organize publications by and about Theosophy, Baha'ism, and other religions. By comparison, Smith-Watson classification was devised specifically for Islamic materials, and remains a landmark in Islamic Studies librarianship.

In 1964 Dr. Smith left McGill for Harvard University's Divinity School, and was succeeded as Director of the Institute by Dr. Charles J. Adams. Although not as preoccupied with librarianship as Smith, Adams continued supporting the Library. During this period the collection enjoyed strong, but uneven development. Until the late 1980s, selection was undertaken by the professors, librarians and students, in that order. Through their efforts and dedication, employing a variety of strategies, the collection grew steadily with titles in many different formats from all over the Islamic world.

In 1954 the Institute borrowed from the Süssenheim collection, Yale University, over 1,000 uncatalogued items in modern Turkish. As the Library's staff possessed the necessary language skill, McGill agreed to catalogue them. In 1959, the catalogued titles were returned to Yale, except for approximately 250 items purchased at 25 cents each. These titles provided the foundation for the Library's Turkish collection, which prompted the research and writing of the seminal work by Dr. Niyazi Berkes, Professor of Turkish studies, The Development of Secularism in Turkey, (McGill University Press, 1964) the first analysis of Kemal Atatürk's secularization policies in the early years of the Turkish republic. $^{24}$

By 1973 the Library held 70,000 volumes including monographs, serials and manuscripts. ${ }^{25}$ Some of these holdings were rare, for example the Urdu serial titles acquired by the Librarian, Muzaffar 'Ali (1967-1976), during his trips to Pakistan. Other holdings of interest include the Turkish incunabula publications by İbrāhīm Müteferrika, of which McGill has sixteen of eighteen titles. These are noteworthy not simply because they are incunabula but also because only four other libraries are known to have such a large number. The Müteferrika press was a landmark in the Islamic world. It illustrated the effectiveness of the printing press, otherwise viewed with trepidation. ${ }^{26}$

\section{Partington Report: 1984}

By 1984 the collection had grown to 80,000 items. ${ }^{27}$ Even though the Library's central role within the Institute was fully acknowledged, there was awareness that more coherent administrative and collection development policies might be in order. As a result, a consultant was hired. In October, 1984, Dr. David H. Partington, Middle East Studies Librarian, Harvard University, undertook the Library's first evaluation. Along with criticisms and suggestions on how best to proceed 


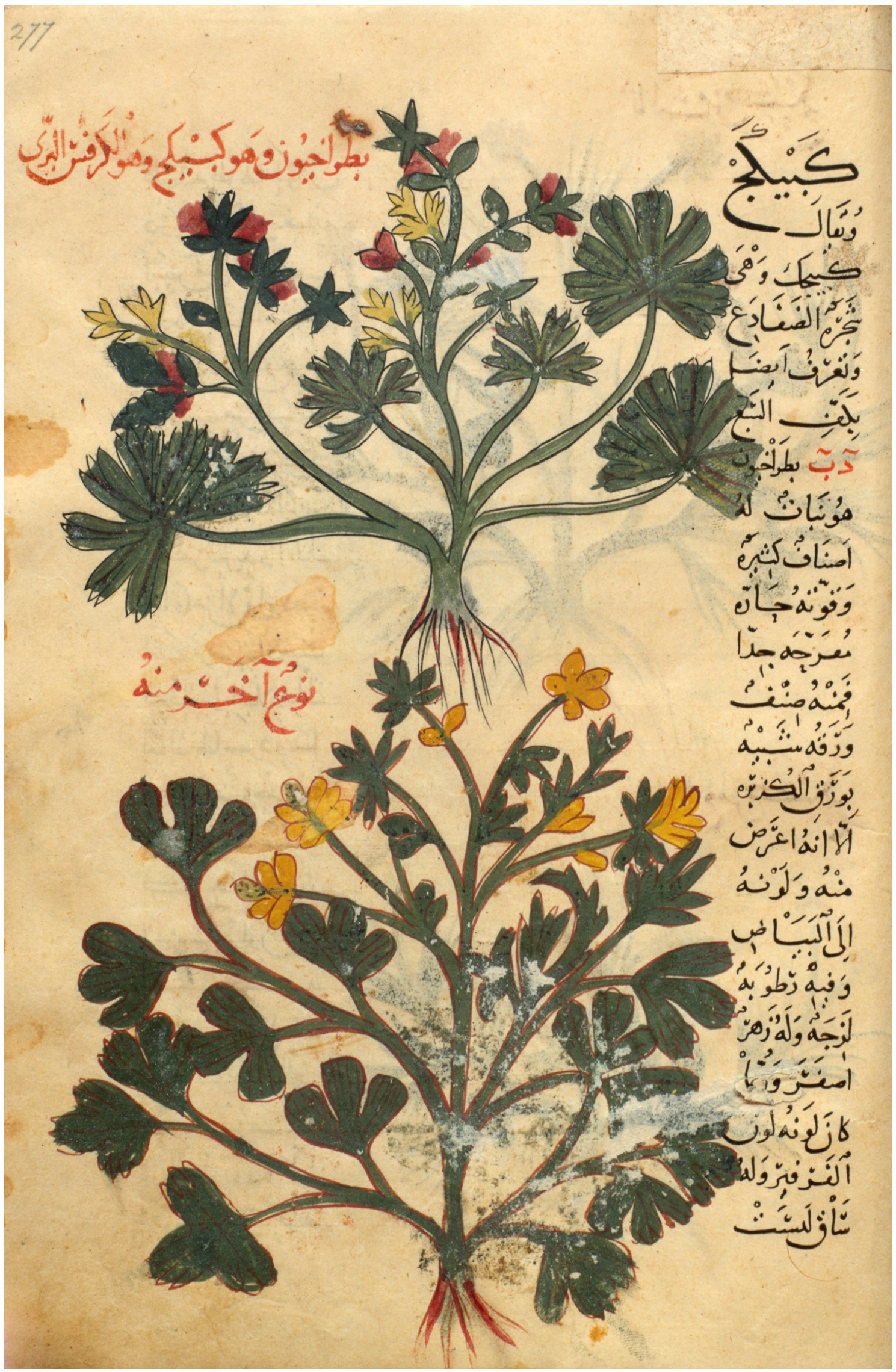

Figure 2. The 'Herbal' manuscript of Abū Ja far Aḥmad ibn Muhammad al-Ghāfiqī 
into the future, his report led to the Library emphasizing the collection as its greatest strength. Partington noted that:

although I read the librarians' annual reports carefully, I have not found evidence of the continued existence of well-organized acquisitions effort. While attention has been paid to acquiring specific titles from European dealers, especially for out-ofprint orientalia, there is little evidence that welldeveloped standing orders were ever instituted. ${ }^{28}$

Partington was generally critical of the Library's management, noting its lack of effectiveness, and the need for intervention by McGill's Library system. The problem was that the Library had two masters, the Director of the Institute and the Director of Libraries, who could easily have divergent views on its role and function. ${ }^{29}$ The predominant voice of the Institute was due, of course, to professors having major responsibility for collection development, and the Institute being the main financial backer. Although Partington did not address the issue directly, the lack of a Head Librarian from the late 1970s until 1987 was symptomatic of managerial problems.

Partington evaluated the collection by shelf reading and searching the catalogue, and by comparing McGill with Harvard's Center for Middle Eastern Studies, founded in 1954, two years after the Institute. This comparison between McGill and Harvard has been a long standing source of concern for observers as the two institutions have such different histories and priorities. The Harvard Semitic language collection development began in the late 17th century while McGill's earliest Islamic collection began in the early 20th century. Harvard's program encompassed Middle Eastern Studies with a strong focus on the social sciences, whereas McGill focused almost exclusively upon the humanities. Unlike McGill, as Partington noted, Harvard strove for an area-wide collection to complement its multidisciplinary research and teaching agenda. Area studies collections developed in the mid-20th century United States, reflecting its world power status. ${ }^{30}$ By comparison, research and teaching at McGill focused upon the humanities with a particular interest in textual analysis-in the classical

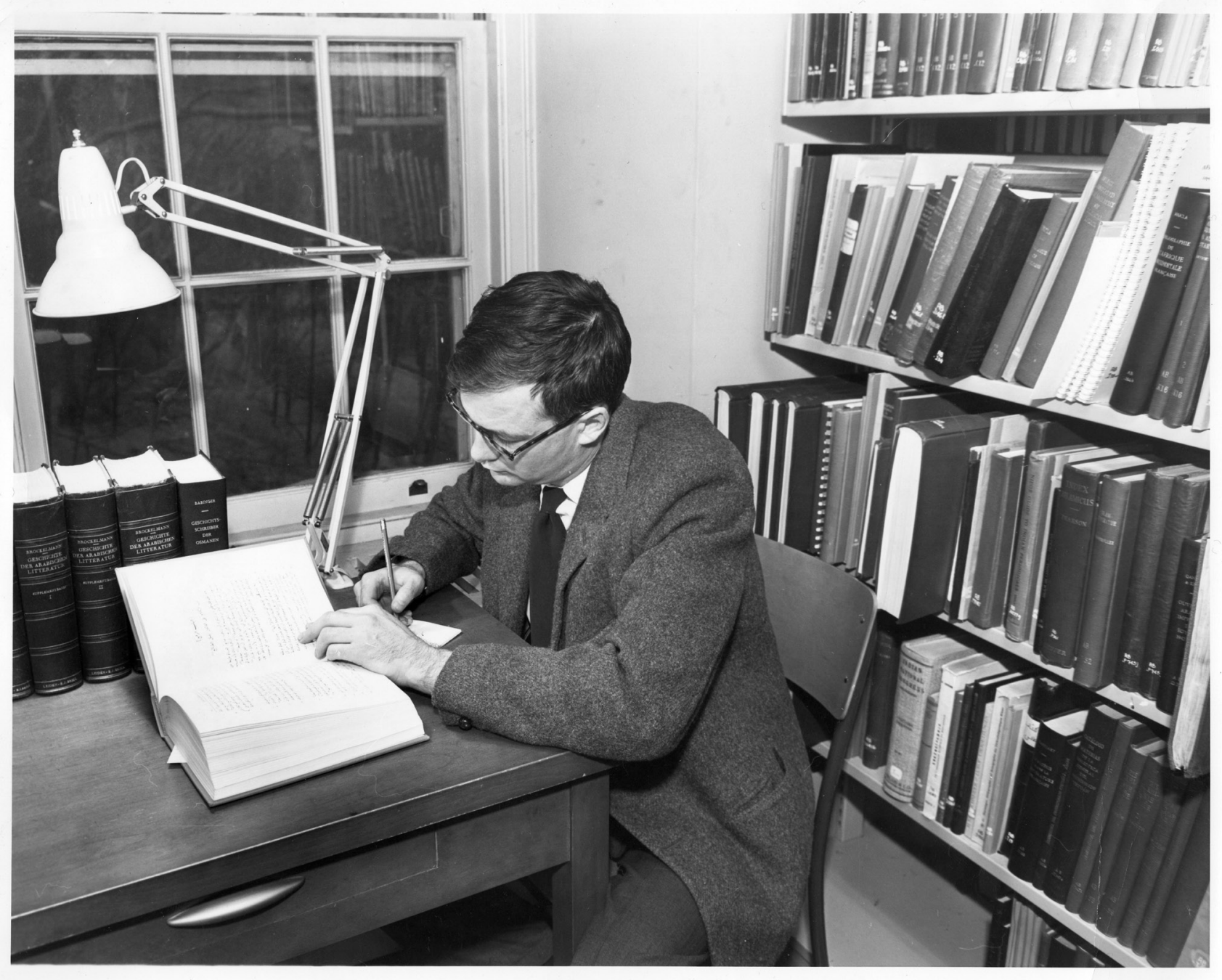

Figure 3. William J. Watson, First Librarian of the Islamic Studies Library, c. 1955 


\section{919 . \\ .S $9663 t$}

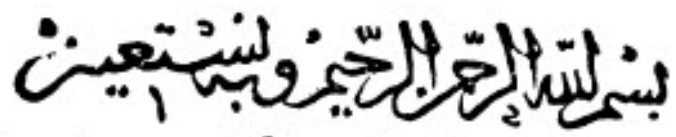

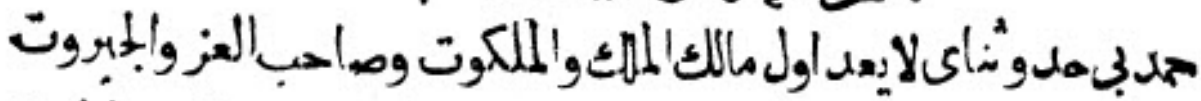

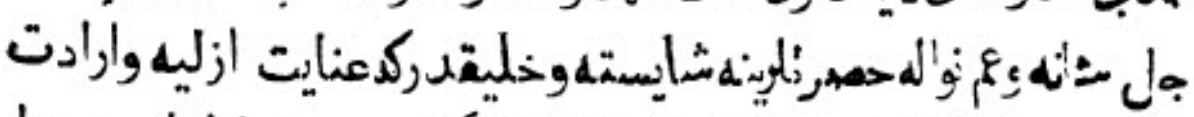

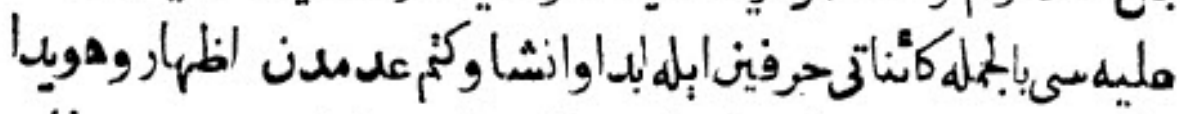

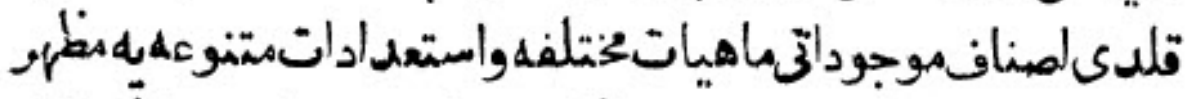

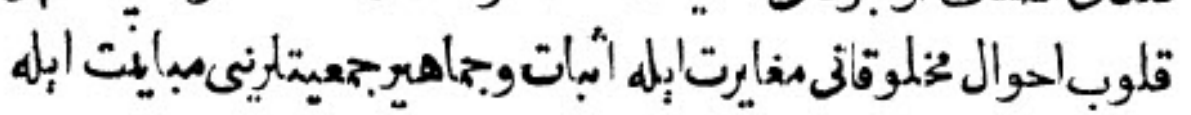

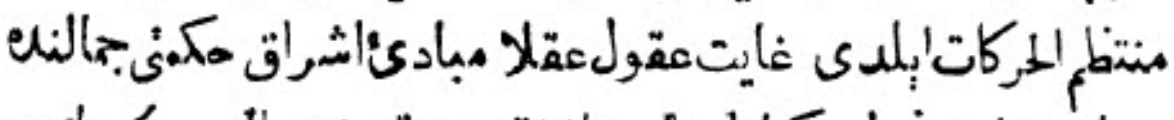

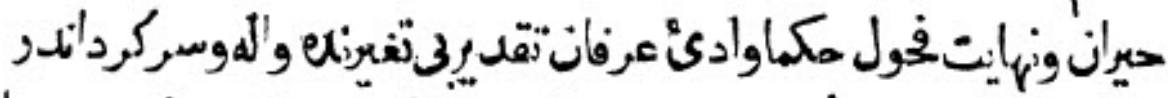

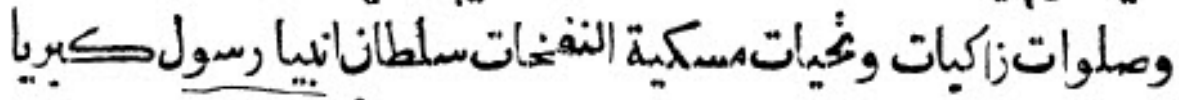

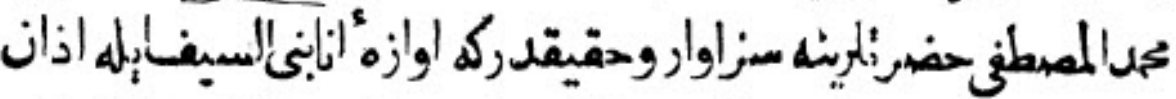

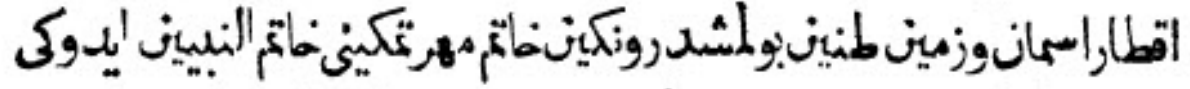

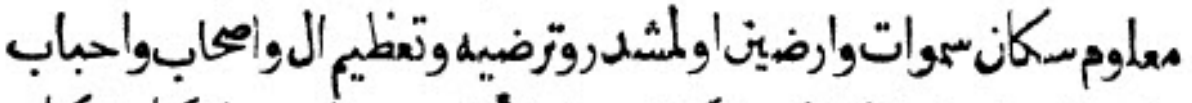

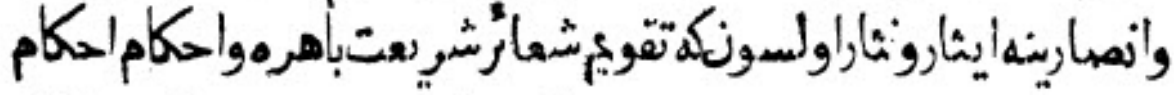

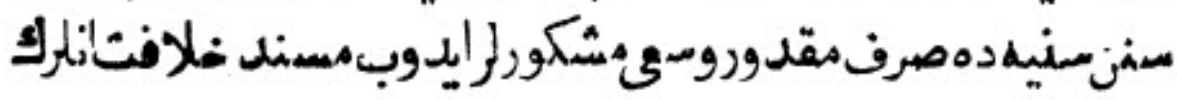

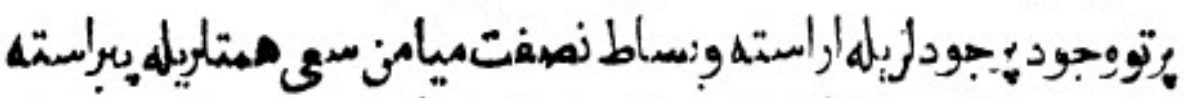

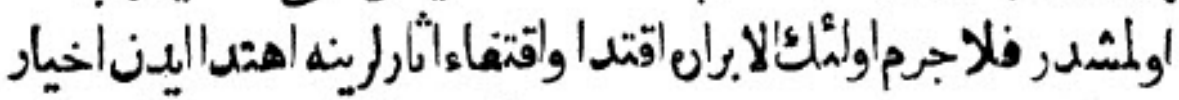

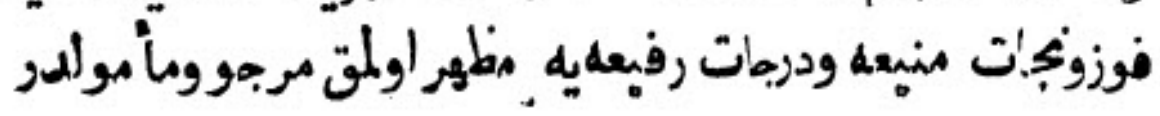
ويعل 
Orientalism style of 20 th century European programs. Finally, unlike Harvard's Center for Middle Eastern Studies, neither the Institute nor its Library was geographically centred, but was focused instead on Islam and the Muslim peoples not only in the Middle East but also in regions not traditionally collected by Harvard such as South, South East, and Central Asia, India and Pakistan.

The overall assessment of the collection was:

good in mainstream, conventional Islamic studies; below strength in Arabic, Turkish, Persian belleslettres; generally good in secondary literature; weak in peripheral areas, such as North Africa and Afghanistan; generally weak in German works on the Middle East; and not strong enough in periodical literature e $^{32}$

Questions can be raised about aspects of Partington's methodology. Sadiq Hidayat (1903-1951) — an important Iranian writer of fiction - was a name used to test the extent of the Library's holdings of important authors, despite his being of peripheral interest to the Institute's area of study. Little or no attention was paid, however, to the Library's strength in Qurānic studies, Tafsīr (Qur'ānic exegesis or commentary), Hadith (sayings and actions attributed to the prophet Muhammad), Sufism (mystical Islam)-topics of major interest to the Institute.

A year later, Ms. Norma Johnston, Religious Studies Librarian, in her role as acting Head of the Library, responded to Partington's report by addressing both collections development and administrative issues. Her critique of Partington's recommendations on collections was balanced and nuanced. She felt that he placed too much emphasis upon collection numbers and too little upon collection development issues such as filling glaring gaps in holdings in areas like audiovisuals and microfilms, and the rare book collection. ${ }^{33}$ Otherwise, they concurred that the collection had

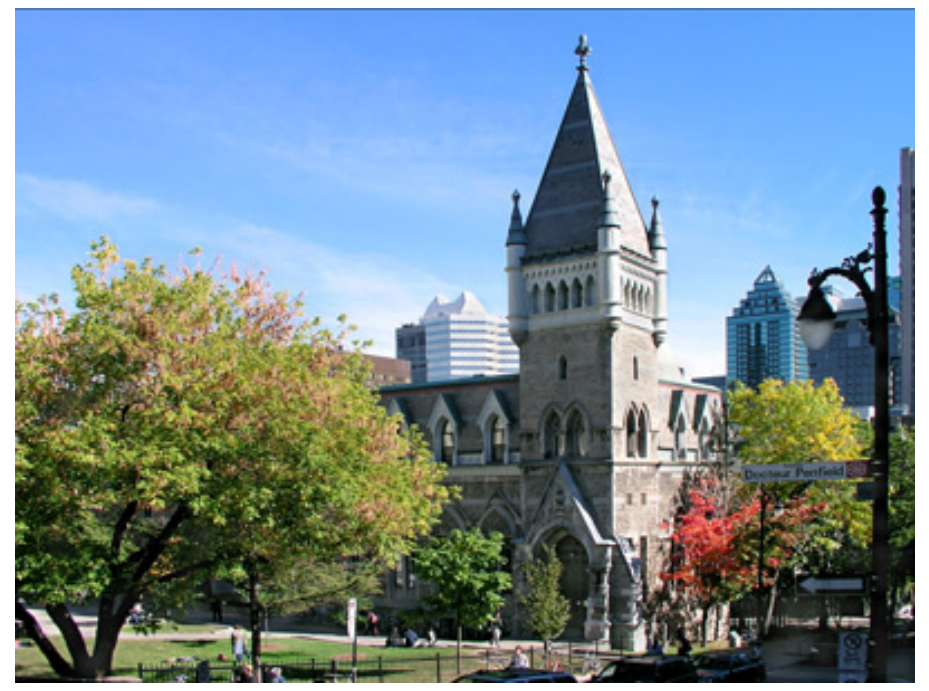

Figure 5. Morrice Hall, c. 1990 grown mostly in fields that interested faculty. The reference collection remained intertwined-conflated-with the regular circulating materials. As for suggestions that a librarian be sent to the Middle East on book buying expeditions, she expressed strong reservations. On the administrative front, Johnston identified two major problems. The first was a lack of a Head Librarian since the late 1970s, and the need for someone with a specialist background. The second was the financial implication of such an appointment. ${ }^{34}$ The Institute remained the main financial backer of the Library. As Johnston noted

for the most part, the funds for books, journals, and binding, and some salaries, have come from special sources other than the McGill budget. ${ }^{35}$

Planning further than a year in advance was precarious given the fluctuation in funding.

\section{Recent Developments}

In 1987, Mr. Adam Gacek, a respected librarian and scholar, Institute of Ismaili Studies in London, England, became head of the Islamic Studies Library. His arrival signalled a change of course for its collection development. The 198788 Annual Report notes that Mr. Gacek spent much time assessing the collection against various Islamic and Middle East Studies bibliographies, and acquiring missing and necessary reference materials notably the Arabic biographical dictionaries identified by University of Exeter Middle East Studies librarian, Paul Auchterlonie. ${ }^{36}$ Creation of a separate reference collection, a periodicals room, and a special collections section in 1989 clearly defined the Library, making it more suitable for serious research. A more appropriate and holistic collection emerged in which the gaping lacunae that had developed over the years, as identified by Partington, began to be filled.

Over the past two decades the Institute and the Library have undergone significant transformation. Collection policy for the Library has been refocusing to reflect the changing research and teaching priorities of faculty and graduate students. Core teaching areas are increasingly concerned with contemporary issues such as Persian anthropology, current Middle Eastern politics and history, and modern Arabic literature. A social science approach to research is supplanting the Institute's long-standing humanities approach. ${ }^{37}$

From a managerial perspective, the Institute's faculty is less involved in the Library's operation and collection development than it had been in the past. Whereas the Institute had previously covered most of the Library's costs, the Library system now provides $95-100 \%$ of its budget. The system's operational and collection's policies are now closely followed. Nevertheless, relations between the Library and its core Islamic Studies faculty and students remain close and collegial. 


\section{Conclusion}

During the past 60 years, the Islamic Studies Institute has become a world-renowned centre for teaching and research. The Library has played a central role in this achievement, through developing outstanding collections that attract scholars from across the world, and through the expertise and commitment to service by its librarians. Evolution and adaptation in meeting the challenges of Islamic and Middle Eastern Studies remains the goal of McGill University's Islamic Studies Library.

\section{ENDNOTES}

${ }^{1}$ P. McNally. 2001. "McGill University Libraries." International Dictionary of Library Histories, ed. by David Stam. Chicago: Fitzroy Dearborn, v. 1, pp. 436-438.

${ }^{2}$ H. Keith Markell. 1979. The Faculty of Religious Studies, McGill University, 1948-1978. Montreal: Faculty of Religious Studies, McGill University, p. 33.

${ }^{3}$ Letter of W.C. Smith to Principal F.C. James, May 26, 1951. McGill University Archives, file number 634 RG84 Container 681043 C.

${ }^{4}$ Hillary Putnam, D. Eck, J. Carman, T. Wei-Ming, and W. Graham. 2001. "Wilfred Cantwell Smith: In memoriam." Harvard Gazette. Accessed 12 February, 2012: http://news.harvard.edu/gazette/2001/11.29/27memorialminute.html

${ }^{5}$ David Webster. 2009. Fire and the full moon: Canada and Indonesia in a decolonizing world. Vancouver: UBC Press, pp.92-95.

${ }^{6}$ Charles J. Adams. 1962. "The Institute of Islamic Studies." Canadian Geographical Journal, 65 (2), p.35.

p.15. 1965. "Understanding the Muslim World." McGill News, 46 (3),

${ }^{8}$ A. Gacek. 1990. "Early Qur'anic fragments," Fontanus, 3, pp. 45-64.

${ }^{9} \mathrm{~S}$. Roman. 1990. The development of Islamic library collections in Western Europe and North America. London: Mansell, p.241.

${ }^{10}$ Wladimir Ivanow, and Casey A. Wood. 1927. "Annotated catalogue of the Casey A. Wood Collection of Persian, Arabic and Hindustani manuscripts." [Photocopy of typescript], located in Rare Books and Special Collections.

${ }^{11}$ A. Gacek. 1991. Arabic manuscripts in the libraries of McGill University: union catalogue. Montréal: McGill University Libraries. 2005. Persian manuscripts in the libraries of McGill University: brief union catalogue. Montréal: McGill University Libraries. 1996. A rabic lithographed books in the Islamic Studies Library, McGill University: descriptive catalogue. Montréal: McGill University Libraries.

${ }^{12} \mathrm{~J}$. Solomon. 2012. "Ancient Secrets Revealed." headway: Research, discovery and innovation at McGill University. Accessed 20 Feb., 2012: http:// publications.mcgill.ca/headway/magazine/ancient-secrets-revealed/; A. Gacek. 1989. Arabic calligraphy and the "Herbal" of al-Ghâfiqî: a survey of Arabic manuscripts at McGill University. Montréal, Québec: McGill University Libraries; and Abū Ja'far Aḥmad ibn Muhammad Ghāfiqī, and Eleonora Di Vincenzo. 2009. Kitab al-'adwiya Al-Mufrada' 'Abu Ga'far'Ahmad b. Muhammad b. 'Ahmad b. Sayidd Al-Gafiqi (XII sec.) : edizione del capitolo 'Alif. Pisa: F. Serra, pp. xix-xxi.

${ }^{13}$ B. Smarchande. 2011. "Notes on a Manuscript of al-Majūsīs Kāmil alSināah and the Wafā̄ìyah Sufi Order in Ottoman Egypt." Unpublished paper.

${ }^{14}$ E. Lewis. 1973. "Current Exhibition-McLennan Library, McGill University Libraries. February-mid March 1973. Persian and Arabic Manuscripts." [Original typescript,] currently at Islamic Studies Library to be transferred to McGill University Archives.
${ }^{15}$ S. Wilson. 1990. "Helping our understanding of Islamic cultural achievements: Rare, exotic, and beautifully written and decorated Arabic works," The Montreal Downtowner (August 15), p.13.

${ }^{16}$ S. Swanick. 2011. Abū Hāmid al-Ghazālī (1058-1111): An exhibition held in the Humanities \& Social Sciences Library, McGill University: August 15, 2011-March 31, 2012. Montréal: McGill University Library.

${ }^{17}$ D. Webster. 2009. Fire and the full moon: Canada and Indonesia in a decolonizing world. Vancouver: UBC Press, p. 93.

${ }^{18}$ [No author.] 1973. "McGill Islamic Library: An introduction." [Draft. Submitted to Dr. Richard A. Farley, Director of McGill University Libraries.] [Original typescript,] currently at Islamic Studies Library to be transferred to McGill University Archives.

${ }^{19}$ W.C. Smith. 1954. "Memorandum on Library Development" (including addendum submitted to Ford Foundation). Original typescript,] currently at Islamic Studies Library to be transferred to McGill University Archives.

${ }^{20}$ W. J. Watson. 1964. "Research Seminar Paper on Library Development." [Original typescript], currently at Islamic Studies Library to be transferred to McGill University Archives. N.B. It seems that the Institute and Library coordinated on a seminar series in the 1960 s until the early 1970 s. There are a number of student essays on the Library, often detailing its collection, history, staff and development. There is no definitive source that I found that explains what course was involved, who taught the seminar or who the audience was.

${ }^{21}$ W.C. Smith. 1954. "Memorandum on Library Development," p. 2. File copy, currently at Islamic Studies Library to be transferred to McGill University Archives.

${ }^{22}$ L.R. Pearson. 1982. "Perils and Pitfalls of Mideast Acquisitions." American Libraries, 13 (2), p. 117.

${ }^{23}$ W. J. Watson. 1964. "Research Seminar Paper on Library Development," p.7. One example of the issues faced when cataloguing Islamic materials, particularly for Arab names is the division of the name. Arab culture, generally speaking and particularly until recently, devised names according to family lineage and often using the surname, as understood in a Western context, from the town, village or city in which an individual was born. Thus, the full name of the eminent medieval scholar Abū Hāmid al-Ghazāli is Abū Hāmid ibn Muhammad al-Ghazālĩ al-Tūsi; Abū signifies the father of Hāmid, ibn signifies the son of Muhammad, al-Ghazālī represents what is known as a laqab, or nickname which is often the unique name of an individual (becoming the surname as understood in the West) and al-Túsi signifies he is from the town of Tüs in northern Iran.

${ }^{24}$ W. J. Watson. 1958. "Osmanli books borrowed from Yale University." McGill University Archives, file number 4366 RG40 Container 442065 B.

${ }^{25}$ [No author.] 1973. "Institute of Islamic Studies." [Original typescript], currently at Islamic Studies Library to be transferred to McGill University Archives.

${ }^{26}$ Alastair Hamilton, Maurits H. van den Boogert, and Bart Westerweel. 2005. The Republic of Letters and the Levant. Leiden: Brill, pp.269-270; Watson, William J. 1968. "İbrāhīm Müteferrika and Turkish incunabula." Journal of the American Oriental Society, 88 (3), pp. 435-441; and Sean E. Swanick, "İbrahim Müteferrika and the printing press: A Delayed Renaissance." Papers of the Bibliographical Society of Canada. : Cabiers de la Société bibliographique du Canada. (Forthcoming, 2014.)

${ }^{27}$ N. Johnston. 1985. "Cyclical Review of the Islamic Studies Library," [original typescript], p.11. Currently at Islamic Studies Library to be transferred to McGill University Archives.

${ }^{28}$ D. H. Partington. 1984. "The Islamic Library at McGill University: A report and evaluation," p.12. File copy, currently at Islamic Studies Library to be transferred to McGill University Archives.

${ }^{29}$ Ibid., p.13.

${ }^{30}$ Labib Z. Yamak. 1968. "The Middle Eastern collections of the Harvard Library." Harvard Library Bulletin XVI (4).

${ }^{31}$ İbrahim Müteferrika, Kâtip Çelebi, and Francis North. 1730. Tarikh al-Hind al-gharbi al-musamma bi-Hadith-i naw. Qusțantiniyah (Constantinople): Dār al-Tỉbā'ah al-Ma'mūrah. 
${ }^{32}$ D. H. Partington. 1984. "The Islamic Library at McGill University: A report and evaluation," p.12. File copy, currently at Islamic Studies Library to be transferred to McGill University Archives.

${ }^{33}$ N. Johnston. 1985. "Cyclical Review of the Islamic Studies Library," p.11. [Original typescript], currently at Islamic Studies Library to be transferred to McGill University Archives.

${ }^{34}$ Ibid., p.12.
${ }^{35}$ Ibid., p.23.

${ }^{36}$ A. Gacek. 1988. "Islamic Studies Library, Annual Report: 1987-88." [Original typescript], currently at Islamic Studies Library to be transferred to McGill University Archives.

${ }^{37}$ M. Abley. 2008. "Understanding Islam," McGill News. Spring/Summer, pp. 23-27. Accessed 20 Feb., 2012: https://publications.mcgill.ca/ mcgillnews/2008/08/24/understanding-islam/. 